\title{
ENGLISH LANGUAGE TEACHING IN ELEMENTARY SCHOOL: EFFECTIVE OR NOT?
}

\author{
Milawati \\ State Polytechnic of Madura \\ milawati@poltera.ac.id
}

\begin{abstract}
Recently curriculum in elementary school has posed the English subject as an extracurricular subject. However, the meeting is done once in a week during effective learning hours. It challenges the English teacher to formulate English learning activities. This study is aimed to describe the teaching-learning activities, including the English teacher's strategy, material, and media. An English teacher and 29 students of 4A were chosen as the subjects. Mix methods; observation, interviews, and questionnaires were chosen to collect data. The results of observation indicate that the English teacher has the ability in explaining, managing, communicating and evaluating the students. On the contrary, negative responses towards the media used, the attitude, and the benefit of the media were also shown by students' responses. Mainly, they thought that some of what they get did not match with their expectations. Some changes to create effective English teacher strategy and students' participation are discussed.
\end{abstract}

Keywords: K13 curriculum, ELT for young learners, elementary school.

\section{INTRODUCTION}

The polemic about learning English in elementary schools is sticking out since at the end of 2013. The pros and cons of the importance of learning English in elementary schools arise from various groups with various considerations. One of them is concerning the fading of nationalism which is instilled early on because foreign language skills were assumed that it could interfere with the process of acquiring mother / local language and Indonesian language. The introduction of English in elementary school is an effort to prepare students to learn English in advance degrees. It is reasonable that recently English is becoming a favorite local content both in the rural and urban areas. It can be seen from many schools in Bangkalan which has introduced English early and become local content starting in grade 1 elementary school. It can also be understood that learning English is considered important as a means of introduction for elementary students about English as an international language.

In line with the above condition, the Ministry of Education and Culture which was officially approved that English is only local content. When the 2013 curriculum occurs the streamlining of the number of subjects and does not bring up English lessons, then English appears in the selected extracurricular (Kemendikbud, 2013). The emergence of English in this extracurricular provides opportunities for schools to choose according to the needs of students. This of course also relates to the area where the school is located and students live. 
Apart from the pros and cons, the implementation of the 2013 curriculum which includes English in extracurricular activities is becoming a challenge for elementary school English teachers and academics to formulate these extracurricular activities. This research was conducted in elementary schools throughout the Bangkalan regency because early English learning in this region was considered necessary. The number of emerging tourist villages and foreign tourists who have and will stop in Bangkalan demands that learning English as an international communication tool for citizens is very important. Thus, based on the results of the research that has been presented, the focus of this study is the description of elementary school English learning by implementing the 2013 curriculum.

\section{English in Elementary School Based On K-13 Curriculum}

In the 2013 curriculum, English subjects are no longer in the category of local content subjects but are replaced by extracurricular activities that are not required to be taught in schools. Even in 2016/2017, English subjects must be removed from elementary school. However, in the 2013 curriculum, English subjects are still allowed to be taught as extracurricular with various changes. According to the Ministry of Education and Culture (2013), five basic things need to be considered in the 2013 curriculum for Language subjects. First, the material being taught is emphasized on language competence as a communication tool to convey ideas and knowledge, it means that the material being taught is no longer emphasized on grammar/language structure as happened in the previous curriculum. Second, students must be accustomed to reading and understanding the meaning of texts and summarizing and re-presenting them in their language.

Whereas in the old curriculum students were only asked to repeat what had been read. Third, students are accustomed to compiling systematic, logical, and effective texts through exercises in the preparation of texts which did not occur in the previous curriculum. Fourth, students are introduced to the appropriate text rules so that they are not confused in the process of the preparation of the text (according to the situation and conditions: who, what, where). Fifth, students Accustomed to being able to express himself and his knowledge with a language spontaneously convincing. Learning English in elementary schools focus on what is needed by students in everyday life. Also, productive skills such as writing and speaking are more emphasized. Although receptive skills such as listening and reading are also taught, both taught to strengthen and hone productive skills (as seen in Table 1).

Table 1: The 2013 Curriculum for the English Language

\begin{tabular}{|l|r|}
\hline \multicolumn{1}{|c|}{ KTSP Curriculum } & \multicolumn{1}{|c|}{ K13 Curriculum } \\
\hline $\begin{array}{l}\text { 1. The material taught emphasizes on } \\
\text { grammar/structure of language }\end{array}$ & $\begin{array}{l}\text { 1. } \\
\text { The material taught emphasizes on } \\
\text { language competence as a } \\
\text { communication tool to convey } \\
\text { ideas and knowledge }\end{array}$ \\
$\begin{array}{l}\text { 2. Students are not accustomed to } \\
\text { reading and understand the meaning } \\
\text { of the text presented }\end{array}$ & $\begin{array}{l}\text { 2. } \\
\text { Students are accustomed to } \\
\text { reading and understand the } \\
\text { meaning of texts and summarizing }\end{array}$ \\
\hline
\end{tabular}




\begin{tabular}{|c|c|}
\hline & and re-presenting in their language \\
\hline $\begin{array}{l}\text { 3. Students are not accustomed to } \\
\text { compiling texts that are systematic, } \\
\text { logical, and effective. }\end{array}$ & $\begin{array}{l}\text { 3. Students are accustomed to } \\
\text { compiling texts that are systematic, } \\
\text { logical, and effective through } \\
\text { exercises in the preparation of } \\
\text { texts }\end{array}$ \\
\hline $\begin{array}{l}\text { 4. Students are not introduced to the } \\
\text { rules of the text that suits their needs }\end{array}$ & $\begin{array}{l}\text { 4. Students are introduced to the } \\
\text { appropriate text rules so that they } \\
\text { are not confused in the process of } \\
\text { preparing the text (according to the } \\
\text { situation and conditions: who, } \\
\text { what, where) }\end{array}$ \\
\hline $\begin{array}{l}\text { 5. Students are Less emphasized on the } \\
\text { importance of expression and } \\
\text { spontaneity in language }\end{array}$ & $\begin{array}{l}\text { 5. Students are accustomed to being } \\
\text { able to express themselves and } \\
\text { their knowledge in spontaneous } \\
\text { convincing language }\end{array}$ \\
\hline
\end{tabular}

Source from Kemendikbud (2013)

\section{Concepts of English Extracurricular Learning}

Recently English has posed as an extracurricular subject. Although it has become extracurricular, the concept of English extracurricular learning in elementary schools has not been clearly explained in the 2013 curriculum. Thus, schools and English teachers have difficulty when implementing English language policies as extracurricular. To overcome this difficulty, the Ministry of Education and Culture through Decree number: 0128 / MPK / KR / 2013 dated June 5, 2013, addressed to all Heads of Provincial / District / City Education Offices throughout Indonesia, gave freedom to schools to develop curriculum 2013 independently adapted to conditions in the school. Thus, extracurricular activities, in this case, can be interpreted as activities carried out by students outside of study hours as stated in the standard curriculum. Extracurricular activities aim to make students able to develop themselves including the development of personality, talents, interests, and abilities in various fields outside the academic field. This activity is usually held and funded independently by the school and the students themselves. That means that English extracurricular activities will be carried out outside of student learning hours at school by following the rules set by the Ministry of Education and Culture in the 2013 Curriculum as listed in table 1 above.

Besides, Abduhzen (2013) emphasized that English subjects must be included in extracurricular activities so as not to burden students at school. English learning activities must be presented in a cheerful, relaxed and uplifting atmosphere so that the language sciences are easily absorbed and digested. Because the goal of elementary school extracurricular learning is as communicative as is needed in daily life, the learning design must be close to the needs of students and practice productive skills (speaking and writing). 


\section{METHOD}

This study will describe elementary school English learning by implementing the 2013 Curriculum. This study uncovers natural phenomena (naturalistic) conducted by the subject when implementing English learning and the main instrument is the researcher himself. Therefore, this type of research is exploratory research, while the research approach is qualitative. The subjects in this study were fourth grade A students of SDN Demangan 1 Bangkalan Academic Year 2019/2020 with 1 English teacher. The third-grade elementary school students were chosen as research subjects because these students assumed that they were able to communicate oral and written.

In addition to the researcher as an instrument in this study, the researcher was assisted with supporting instruments, namely (a) English language learning instrument documents for the 2013 curriculum (b) observation sheet instruments for English teacher and student activities, and (c) student questionnaire instruments. After the research subjects are selected, then to collect data related to research questions, researchers need data regarding the activities of elementary students and English teachers when learning English. The data collection process in this study is: collecting documents on English language learning tools for grade 4 elementary school, observing the activities of English teachers and students when learning English takes place. In this case, the researcher records the verbal and nonverbal expressions of students and English teachers and records the behavior (expressions) of students and English teachers including the unique things that the subject does when the learning takes place. Furthermore, researchers interviewed subjects related to aspects related to English language learning using the 2013 curriculum. When one subject has been completed, the same thing is done to other subjects, to obtain the desired data.

Credibility in this research is by triangulation. The triangulation of interview data in this study uses the triangulation of sources at different times, namely comparing and checking data or information from the results of documents, observations, and interview results obtained through different times. So that researchers may re-interview on the same subject, then compare the results of the interview at different times. In addition to triangulation, researchers also performed other techniques, namely matching data from research results through discussion of subjects and peers to examine data or information, interpretations of the results of prepared reports.

Regarding data analysis process in this study consisted of categorizing data related to, materials, strategies, and media that are relevant to this research. Afterward reducing unnecessary and irrelevant data. Exposure to the data that has been categorized, then performed data checks to determine the consistency of information provided by the subject to obtain credible research data (triangulation of data). Next is interpreted data as a process of understanding the meaning of a series of data that has been presented. Then a discussion and compare credible research results data were conducted with certain literature and theories to describe elementary English learning with the 2013 curriculum. Last, concluding by formulating meaning from the results of research based on the results of the discussion of the data collected. 


\section{FINDINGS AND DISCUSSION}

The results of this study are based on problems in the research that are related to English teacher teaching strategies, teaching materials and instructional media used in the classroom.

\section{Findings}

This research was conducted in 4 meetings, namely 22 and 25 July, 1 and 8 August. The observations were carried out at three meetings and ended with questionnaires at the last meeting. Based on observations obtained at meetings 1 student in grade 4A is still doing a basic introduction with the new English English teacher. At meetings $2 \& 3$ the teaching and learning process was discovered. In the second meeting, the English teacher gave a talk about "simple present" and the third meeting about "daily activities". Learning takes place in one meeting 2 x 30 minutes or equivalent to 1 hour. 15 minutes before school hours are used to condition students at 7.00. Students were conditioned by the English teacher to be in the classroom, by starting to read prayers, then proceed to read the Yasin letter, and singing the national anthem Indonesia Raya. While in a separate room, the English teacher prays in the English teacher's room. At 7.15 the English teacher enters the classroom and starts the teaching and learning process.

Overall from 2 consecutive meetings namely the second and the third meetings, I obtained several English teacher strategies in explaining teaching material, managing classes, communicating and evaluating students. The following will be described:

\section{English teacher strategies in explaining the material}

In explaining the subject matter, the English teacher appears to master the subject matter. This can be seen when the English teacher explains, can develop teaching materials by learning objectives. Also, the English teacher can deliver material by including examples that are relevant to students. By paying attention to the systematic delivery order from the easiest to the most difficult.

$\mathrm{Q}$ : anyone knows simple present tense?

S1 : I know ma'am. Daily use

$\mathrm{T}$ : like what?

S1 : I eat 3 times a day.

$\mathrm{Q}$ : What do these simple present uses mean?

S1 : Habit ma.

The dialogue excerpt above is a dialogue that was taught by an English teacher above, showing that an English teacher in delivering material by giving questions directives starting from easy questions to the most difficult.

\section{Class management strategy}

Based on observations found that in classroom management, English teachers often give warnings to students who are not paying attention, the English teacher explains loudly by using a loudspeaker that is "mix", the English teacher occasionally approaches students who have difficulty, and focuses attention on all students. But not too many, students passing by, approached the English teacher to ask questions. 


\section{Communication strategies with students}

English teacher and student communication occur a lot in the core activities, after the English teacher explains, often the English teacher provides an opportunity for students to ask questions. This is done to anticipate students' difficulties in capturing learning material. Besides, the English teacher also uses language that is more easily understood by students.

\section{Strategies for evaluating students}

Based on observations of meetings 1 and 2, the English teacher evaluates at the end of the lesson such as giving assignments, correcting students' homework, daily tests. Or give practice questions, after the English teacher explains.

\section{Teaching materials}

Based on observations it is also known that teaching materials used by students are books. In this case, the English teacher combines teaching materials from 3 different curricula, namely 1994, 2006 and 2013. The three books used in teaching English for grade 4, namelyy English for beginners; English for grade 4 elementary schools (Priyanto, 1994); Grow with English; an English course for elementary school students book 4 (Mukanto, 2006); Basic English skills; English activities for elementary school students grade IV (Lidwina, 2014) and Basic English New edition for Elementary School Year IV (Sulaiman and Ament, 2016).

\section{Instructional Media}

Learning media that are often used by English teachers, among others, films and pictures. From the results of the questionnaire obtained data regarding student responses related to media use, student attitudes, and media benefits for students, overall it can be said to be good. Although the frequency of use is still sometimes used. More details can be seen in the results of the calculation of the questionnaire given to students at the end of the meeting.

Tabel 2: The result of Students' Response

\begin{tabular}{|l|l|r|r|r|r|}
\hline No & \multicolumn{1}{|c|}{ Pertanyaan } & SL & SR & KK & TP \\
\hline \multicolumn{1}{|c|}{ The use of Media in the Teaching-Learning Process } & & 13 & 9 & 7 & 2 \\
\hline 1 & $\begin{array}{l}\text { English teacher uses media in the teaching- } \\
\text { learning process }\end{array}$ & 13 & 11 & 6 & 1 \\
\hline 2 & $\begin{array}{l}\text { English teacher uses various media in the } \\
\text { teaching-learning process }\end{array}$ & 8 & 10 & 13 & \\
\hline 3 & $\begin{array}{l}\text { English teacher uses the handbook as the main } \\
\text { source }\end{array}$ & 11 & 16 & 3 & 1 \\
\hline 4 & $\begin{array}{l}\text { English teacher can use various media in the } \\
\text { teaching-learning process }\end{array}$ & $\mathbf{4 5}$ & $\mathbf{4 6}$ & $\mathbf{2 9}$ & $\mathbf{4}$ \\
\hline Total &
\end{tabular}




\begin{tabular}{|c|c|c|c|c|c|}
\hline \multicolumn{2}{|r|}{ Students' Attitude toward Media Used } & \multirow[b]{2}{*}{11} & \multirow[b]{2}{*}{9} & \multirow[b]{2}{*}{11} & \\
\hline 5 & $\begin{array}{l}\text { I am easy to understand the material if the English } \\
\text { teacher uses the media }\end{array}$ & & & & \\
\hline 6 & $\begin{array}{l}\text { I am easy to get bored if there are No. media used } \\
\text { by the English teacher }\end{array}$ & 4 & 2 & 13 & 12 \\
\hline 7 & $\begin{array}{l}\text { I am motivated to learn English because the } \\
\text { English teacher uses the media }\end{array}$ & 9 & 12 & 10 & \\
\hline 8 & $\begin{array}{l}\text { I feel nervous or worried when I am learning } \\
\text { English }\end{array}$ & 1 & 4 & 5 & 21 \\
\hline \multicolumn{2}{|c|}{ Total } & 25 & 27 & 39 & 33 \\
\hline \multicolumn{6}{|c|}{ The frequency of Media Used } \\
\hline 9 & English teacher only uses the media eventually & 8 & 9 & 13 & 1 \\
\hline 10 & $\begin{array}{l}\text { English teacher always uses media in the teaching- } \\
\text { learning process }\end{array}$ & 10 & 16 & 5 & \\
\hline 11 & $\begin{array}{l}\text { English teacher always uses media when practice } \\
\text { speaking class }\end{array}$ & 4 & 9 & 12 & 6 \\
\hline & teaching media & & & & \\
\hline 12 & English teacher always uses media in Laboratory & & 5 & 14 & 12 \\
\hline 13 & $\begin{array}{l}\text { An English teacher can not use the media } \\
\text { optimally }\end{array}$ & 2 & 4 & 8 & 17 \\
\hline \multicolumn{2}{|c|}{ Total } & 24 & 43 & 52 & 36 \\
\hline \multicolumn{6}{|c|}{ The benefit of using media } \\
\hline 14 & $\begin{array}{l}\text { I get the benefit of the English teacher teaching } \\
\text { media }\end{array}$ & 17 & 8 & 5 & 1 \\
\hline 15 & $\begin{array}{l}\text { I am easy to understand the material taught } \\
\text { without media }\end{array}$ & 7 & 9 & 13 & 2 \\
\hline 16 & $\begin{array}{l}\text { I get easily understand the material by using the } \\
\text { media }\end{array}$ & 8 & 10 & 11 & 2 \\
\hline 17 & $\begin{array}{l}\text { I feel so motivated because the media make me } \\
\text { love English lesson }\end{array}$ & 10 & 9 & 8 & 4 \\
\hline 18 & $\begin{array}{l}\text { I can not get the benefit of teacher teaching } \\
\text { media }\end{array}$ & 1 & 3 & 6 & 21 \\
\hline \multicolumn{2}{|c|}{$\begin{array}{ll}\text { Total } \\
\end{array}$} & 43 & 39 & 43 & 30 \\
\hline
\end{tabular}


From the above table, it indicates that English teacher often uses a variety of learning media that is related to the questionnaire results data which states $37 \%$ states often use and $36 \%$ always use. Related to students' attitudes towards the use of media obtained $39 \%$ of students prefer to take English lessons using the media and $40 \%$ of students feel satisfied following the lesson if there are no media.

Judging from the frequency of using the media, the results of the questionnaire showed 52\% of students stated English teachers often use media. While the benefits of instructional media are greatly felt by students because they can be more easily understood by the lesson, this is seen in questions no. 14 and 16. 55\% claim to feel the benefits and $36 \%$ approve the benefits for utilizing the lesson.

\section{DISCUSSION}

In short, from the results of the above research, it can be said that learning English in the 2013 curriculum, pedagogical approach is very important for teaching children. Overall, English teachers can teach using teaching strategies with a pedagogical approach that is adapted to the characteristics of students including English teachers being able to explain material using simple language, managing classes by giving attention to all classes, approaching students who experience difficulties, communicating with students and evaluating students well. This is in line with what was said (Freiberg \& Driscoll, 1992; Philips, 2000; Sabilah, 2004).

Besides that, the selection of teaching materials and the use of appropriate media can facilitate students to understand the lesson. This is in line with what Heinich (1993: 66) said that visual media can increase students' interest in what has been explained by the English teacher because there are concrete instructions. Moreover, the English teacher chooses the media by adjusting the material, learning objectives and student interest, such as what Ornstein's (1990: 320) has stated, that is, the right media can succeed in student learning.

\section{CONCLUSION}

From the results and discussion of the research, it can be concluded that the 2013 English language learning curriculum, is inseparable from the English teacher's pedagogical abilities, the selection of appropriate teaching materials, and the use of media that is tailored to student interests, teaching materials, and learning objectives. All of these are important factors in learning, to create an atmosphere of effective and conducive teaching and learning in the classroom. However, regarding English teacher teaching methods need to be improved, more student-centered, more interactive and communicative. The frequency of the media can be used more often in the classroom, so students could be more easily understand the material being taught. Last, further research is needed related to the implementation of the 2013 curriculum in learning English.

\section{ACKNOWLEDGMENTS}

This research was funded by the DIPA State polytechnic of Madura. It is a month pilot project in collaboration with The Education authorities in Bangkalan, especially the head of SD Negeri Demangan I Bangkalan. 


\section{REFERENCES}

Freiberg, H. J \& Driscoll A. (1992). Universal Teaching Strategies. London: Allyn and Bacon

Heinich, R., Molsenda, M., and Russel, J.D..( 1993). Instructional Media and the New Technology of Instruction. New York: Macmillan Publishing Company.

Kementerian Pendidikan dan Kebudayaan. (2013). Kerangka Dasar dan Struktur Kurikulum 2013.

Koran Sindo. (2014). Mata pelajaran Bahasa Inggris di sekolah di hapus. http://koran-sindo.com/node/350303 Retrieved 5 Mei 2014

Latief, M.A. (2014). Research Methods in Language Learning: An Introduction. Malang: UM Press.

Miles, B. Matthew, \& Huberman, Michael. (2016). Qualitative Data Analysis: An Expanded Sourcebook. California: Sage Publications.

Radar Madura. 2014. Guide Kota Bangkalan Lemah di Bahasa Inggris. radarmadura.co.id/guide-kota-bangkalan-lemah-di-bahasa-inggris-5042.

Orstein, A. C. (1990). Strategies for Effective Teaching. New York: Harper Collins.

Philips, Sarah. (2000). Young Learners. Hongkong: Oxford University Press.

Sabilah, Fardini. (2004). Teaching English to Young Learners; Its Policy, Framework, and activities -based teaching. Unpublished students' Book. Universitas Muhammadiyah

Sabilah, Fardini, et al. (2009). English for Elementary School Teachers. Malang: UMMPress.

Sugiyono. (2011). Metode Penelitian Kombinas (Mixed Methods). Bandung: Alfabeta.

Sulaiman and Ament. (2016). Basic English for elementary School Year IV new edition. Jakarta: Yudhistira

Tempo. (2012). 9 DesaWisata dikembangkan di Bangkalan. http://www.tempo.co/read/news/2012/06/19/199411553/9-Desa-WisataDikembangkan-di-Bangkalan. Retrieved 5 Mei 2014 